\title{
Spiritual Tourism: a Case Study of Foreigners' Participation in The Pitrayajna Ceremony in The Desa Pakraman of Muncan, Selat, Karangasem, Bali
}

\author{
Nararya Narottama
}

Lecturer at The Bali International Tourism Institute

Corresponding author: naro_osh@yahoo.co.id

\section{ARTICLE INFO}

Received

21 October 2015

Accepted

13 February 2016

Available online

07 March 2016

\begin{abstract}
The influence of globalization appears to occur worldwide and affect any joint of life, including small village near Mount Agung, named Muncan Pakraman village, Karangasem, Bali. When the series of Pitrayajña ceremonies (Balinese traditional cremation series) took place in 2009 at this village, a lot of foreigners from various countries got involved, includeing Germany, Turkey, Israel, the Netherlands, UK, Spain, Belgium and Italy. They were involved not only as a spectators or tourists, but participated in the ceremony for their ancestors, and deceased loved ones and took part in "Ngayah" (working together and voluntarily, without being paid). Pitrayajña ceremony is processions of sacred ceremonies, which usually performed only by Hindus, especially in Bali, was also participated by foreigners (international students of Ratu Bagus Ashram), who were having a spiritual journey to find their true identity. Formally, they were not Hindus, but believed in the teachings of the Hindu religion, and their activities are form of spiritual tourism implementation in Bali. The main problem of research is to reveal how the phenomenon of deconstructing Pitrayajña ceremony in Bali, how the participation of foreign persons in this ceremony, what motivated them, what was the public perception of the deconstruction of Pitrayajña ceremony, the views of the Hindu leaders in Bali to the deconstruction of the Pitrayajña ceremony and whether there was a change of meaning, if the changes are purely the universality of Hindu religion itself, how its impact on society, and its relation to spiritual tourism. With the formulation of a clear scope, this research is also expected to produce maximum findings.
\end{abstract}

Keywords: pitrayajña, globalization, foreigners, participation, deconstruction, spiritual, tourism

\section{Introduction}

Pitrayajña ceremony is the Balinese community effort to keep their balance, as well as holding various religious activities, as the implementation of the teachings of Hinduism. For Hindus, this ceremony is very important, for that reason, people of Pakraman Muncan, Karangasem held Pitrayajña mass ceremony in 2009, the ceremony was initiated by the Maha Gotra Pasek Sanak http://ojs.unud.ac.id/index.php/eot
Sapta Rsi (MGPSSR) of Village of Muncan.

The impact of globalization seems to have occurred throughout the world and affects every facet of life. When the processions of Pitrayajña ceremony took place, there were several foreigners from various countries took part, they came from Germany, Turkey, Israel, the Netherlands, England, Spain, Belgium and Italy. 
They also participated in the ancestral ceremonies of the deceased parents and the beloved ones. They were engaged not just as spectators or tourists. However they participated in the "ngayah" (working together voluntarily, without being paid) and together with the community to hold various sequence of processions such as cremation, mamukur and Ngalinggihang Dewa Hyang, there were nine foeigners' Sawa (Soul) in the ceremony.

They are not Hindus formally, but they believed in the teachings of Hindu religion, it was one form of implementation of spiritual tourism in Bali. All foreigners involved were the students of Ratu Bagus Ashram, they were taking a spiritual journey to find the true self and healing through yoga and meditation.

\section{Research Objectives}

1. What were the forms of participation of foreigners in a ceremonial procession of Pitrayajña in the Desa Pakraman of Muncan?

2. What was the motivation of foreigners in following the ceremony of Pitrayajña in the Desa Pakraman of Muncan?

3. What was the impact and significance of the participation of foreigners in following the ceremony of Pitrayajña in the Desa Pakraman of Muncan?

\section{Literature Review}

Research on the processions of Pitrayajña ceremony, especially cremation has been done, as well as research on Bali, spiritual travel and participation of foreigners. However, it has not been found a previous study that specifically discussed the participation of foreigners in Pitrayajña ceremony in Bali.
The previous studies examine: The Cremation Ceremony of Matempung In the Village of Gadungan Sub-District of Eastern Selemadeg, the Tabanan Regency, Analysis of Form, Function and Meaning (Suastini, 2007), The Perception of Tourists Toward Ubud Village: An Approach to Tourism Theology (Suardana, 2010), Bali : Tourisme Culturel et Culture Touristique (Picard, 2006), Religion and Tourism: Crossroads, Destinations and Encounters (Stausberg, 2011), as well as numerous books, articles and other academic journals

\section{Spiritual Tourism}

Spiritual tourism is a business services that serve the travelling needs of a person / a group to the tourist destinations (tourism / travel industry) mainly related to the destinations of spiritual activities like meditation, pilgrimage, and so forth (Titib, 2006).

As stated by Shackley (2006), a religious or spiritual travel is often considered as a part of cultural tourism. Bali has been promoting cultural tourism, as well as it is known as one of the world's spiritual tourism destination. In Sharpley (2009), stated that religious sites act as the main focus in the practice of religion, rituals and acts of worship. The religious sites attract people who are motivated by the desire for a religious experience, as well as a peaceful spiritual contemplation, (Shackley, 2006), as well as the motivation for salvation and healing (Eade, 1992).

\section{Religion and Spirituality}

Miguel Covarrubias in his book Island of Bali (1973: 359), describing the death as well as the cremation (Ngaben) in Bali. That for the Balinese, the physical body is just the place for atma, or spirit. Atma is life in every part of the body, from head to toe, but more concentrated in the head. To release the atma 
or spirit out of the dead body, in Hindu belief is conducted through the death rituals. Through a medium, the prayers of the sacred Vedas, to release and return the atma to God. Balinese people still have the notion that the more luxurious and grand the ceremony of cremation, the better the travelling of the spirit in the world of the dead would be, and there are fears among some of the people that a simple ceremony of Ngaben can make the spirits angry, and it could be disastrous for their offspring, Eiseman (2011) in Forshee (2006). Thus, to carry out the cremation ceremony, many Balinese had to sell their family land, inheritance, and borrow some money from the bank, therefore, recently more and more lands were sold and eventually owned by outsiders / foreigners. Many Balinese people feel burdened by the implementation of the expensive costs of Ngaben, cremation ceremony.

However, access to information and knowledge has given a new awareness for the people, especially among the younger generation, that a good Ngaben must be in accordance with the religion, and it does not necessarily have to be fancy. There have been so many people who are now turning to the small cremation ceremony and the collective cremation. In addition to saving cost and time, as this form of cremation also can foster a sense of brotherhood among families and communities.

\section{Rituals of Pitrayajna}

In the Vedas (Hindu scriptures) it is stated that the spirit of the deceased will soon be Pitr (Dakshinaranjan, 1990: 1), and then the death ritual must be held, where the remains have to be cremated. The death ritual ceremony is called Pitrayajña. Pitrayajña ceremony in India is called by the name Pitrameda (Dakshinaranjan, 1990: 20), the processions of the cremation ceremony consist of:

1. Antyeûpi ceremony, i.e. the cremation http://ojs.unud.ac.id/index.php/eot ceremony. This ceremony is also called måtyusaýskàra (Klostermaier, 1990) or Ngaben

2. Pitrapinda or Mamukur ceremony, which is an offering of rice porridge (in Bali is called porridge of 'pawilet' or 'bubuh Pitara' in the cremation ceremony),

3. The final ceremony is a ritual of Shraddha (Basham, 1984; Klostermaier, 1990). In Bali, the ceremony is better known as Devapitrapindha, Atmasiddhadevatà, more commonly called Nuntun or Ngalinggihang Dewa Hyang.

The purpose of the implementation of all of the above ceremonies is delivering the ancestors' spirit headed to Pitraloka (nature of the Pita), and that they would be in the hereafter.

\section{Theory of Deconstruction}

The notion of the theory of deconstruction is to reject the view that the language has a definite meaning, as proposed by structuralism (Pujiyanti, 2010). According to the theory of deconstruction, in the reading of literature, is not intended to affirm the meaning as is commonly done, but it usually starts with things that rarely found, never, or not even be thought of, in an attempt to capture the paradoxical meaning, contradictory meanings and irony contained in literature. The elements are deliberately sought and understood in the opposite sense (Nurgiyantoro, 1995).

Theory of Deconstruction was one of the theoretical foundations in this study, because it denies meanings that are considered common in texts, in this case, the theory of deconstruction was used to reject the generalization that the ceremony of Pitrayajña should only be conducted by Hindus in Bali alone, when in fact the ceremony of Pitrayajña in the Desa Pakraman of Muncan, Karangasem, Bali in 2009, was followed by the foreigners who actively participated in it.

e-ISSN: 2407-392X. p-ISSN: 2541-0857 


\section{Theory of Post-Religious}

In her book, The Elementary Forms of Religious Life (1912), Emile Durkheim reviewed religion from the standpoint of sociologistic, among other things: characteristics, source, consequences and the variations. Durkheim thought that religion comes from society itself, and people interpret their God according to their ideals. Thus, people also differentiate the things that are considered sacred and profane. For her, religion is a manifestation of the people's collective consciousness, God becomes a collective representation, where the ideals of the people consider Him as being the most perfect (as the personification of society), omnipotent, and above all things owned or attainable by man (Siahaan, 1986).

In the theory of Post-Religious, spiritual meaning is beyond the concept and layout rules of religion, because spirituality is connecting people directly with the absolute essence that wants to accomplish (the religious people call Him by many names, God, Allah, etc). This theory is used to dissect the motives of the participation of foreigners in the Pitrayajña ceremony in the Desa Pakraman of Muncan, Karangasem, Bali in 2009.

\section{Theory of Semiotics}

Semiotics is the science that discuss and study the science of the signs that have meaning (Pradopo, 1990). Such signs are not just visual signs and signs within the texts, but can also be a process or an event. With signs as an intermediary, so people can interact and communicate with each other and the surrounding environment. Because, signs are the basis of all telecommunications (Relin, 2011).

In this research, semiotic theory was appropriately used to search for the meanings contained in the participation of foreigners in the ceremony of Pitrayajña in the Desa Pakraman of Muncan, Karangasem, Bali in 2009. By looking at the ceremony of Pitrayajña as cultural processions and cultural symbols that contains signs and meanings.

\section{Methodology}

The study was conducted in the village of Muncan, Karangasem, Bali Province from March to June 2009. The data were mostly in the form of qualitative data, with some quantitative data, while the instruments used were photo and video cameras, internet sources (journals, e-mails and articles). Data collection methods were implemented by observation, literature study, interviews, questionnaires and documentation. The informants in this study were: the local people, the foreign participants, experts, academics, traditional and religious leaders. Data were analyzed descriptively and qualitatively.

The scope of the study is limited to two terms, namely:

(1) Limited to the ceremony of Pitrayajña consisting of cremation ceremony, mamukur and Ngalinggihang Dewa Hyang, held in the Desa Pakraman of Muncan, Karangasem in 2009.

(2) Limited to the foreigners who participated in the ceremony of Pitrayajña held in the Desa Pakraman of Muncan, Karangasem in 2009.

\section{Desa Pakraman of Muncan}

In terms of geography, the northern boundary of Desa Pakraman of Muncan, adjacent to the Village of Sebudi, to the east by the River of Kauh Tukad (Village of Peringsari), the southern boundary is the village of Sangkan Gunung, Sub-District of Sidemen and on the west by the River of Yeh Sah, the Sub-District of Rendang. The total area of the Village of Muncan is 10, $64 \mathrm{~km} 2$, which is dominated by rice paddies and fields. Desa Pakraman of Muncan consists of 13 Banjars. 
In everyday life, the Balinese people can not be separated from religious activities. Similarly to the people of Desa Pakraman of Muncan, Karangasem, Bali, which is almost every day enlivened by religious ceremonies. The religious ceremonies such as Pitrayajña (cremation), Odalan or Melasti are often promoted as one of the shows for tourist attraction (Ardika, 2004: 22), especially spiritual tourism and cultural tourism.

\section{Ashram of Ratu Bagus and Bio Energy Meditation}

The development of spiritual tourism in the Pakraman of Muncan is inseparable from the existence of Ratu Bagus Ashram which is located in the village. Since the beginning of 1987, Ratu Bagus Ashram continues to grow, both the physical buildings, and the quality. This growth is a natural process, but the world changes drastically. For that reason, Ratu Bagus try to make this ashram as a high quality healing center to help more people.

Bio Energy Meditation is better known as the shaking meditation, an exercise that could change lives. This is possible with the sacred energy transmission through Ida Mpu Ratu Bagus. This energy transmission, is able to turn the sacred fire which is owned by everyone (kundalini fire), and can be used for either physical, emotional, mental and spiritual healings.

Ida Mpu Ratu Bagus has hundreds of foreign students, who then develop his network throughout the world. Each country has a group that regularly holds meditation of Bio Energy. The countries included in the networks of Ratu Bagus Ashram include: Australia, Belgium, Denmark, France, Germany, the Netherlands, Ireland, Israel, Italy, New Zealand, Spain, Sweden, Switzerland, UK and USA.

http://ojs.unud.ac.id/index.php/eot

\section{The Procession of Pitrayajña Ceremony}

On April 25, 2008 was held a meeting which took place in the Ratu Bagus Ashram, the result of the meeting was that the clan association Maha Gotra Pasek Sanak Sapta Rsi of Village of Muncan agreed to hold the ceremony of Pitrayajña (Ngaben ceremony, mamukur, and Nuntun Dewa Hyang) which was then held on Sasih Kapitu or in January 2009. the processions of the ceremony are as follows:

- The Ngaben ceremony was held on Wednesday, 14 January 2009 at Padunungan (a special place for the cremation ceremony of Ngaben).

- Mamukur ceremony was held on Saturday, January 17, 2009

- Nuntun Dewa Hyang ceremony (atma Pratistha or Ngelinggihang Dewa Hyang) on Friday, January 23, 2009, at Payajñan (at Ratu Bagus Ashram).

\section{Participation of Foreigners}

The word participation can be interpreted as a matter of having participated in an activity. While the framework of UNESCO's cultural statistics in 2009, defines cultural participation as: cultural practices that may involve consumption as well as the activities carried out in the community, which reflects the quality of life, traditions and beliefs. (UNESCO, 2009). Participation can be defined as the involvement of mental / mind and emotions / feelings of someone in a group situation that encouraged him/her to contribute to the group in order to achieve the objectives and co-responsible for the business concerned (Sastropoetro, 1988; Suciati, 2006).

Pitrayajña ceremony is organized by the clan group of Maha Gotra Pasek Sanak Sapta Rsi of Desa Pakraman of Muncan in 2009, in collaboration with other residents, among others, from the clan group of Tangkas Kori Agung, Kayu Selem, Kutawaringin, and 
Pulasari and Ratu Bagus Ashram. The Pitrayajña ceremony was held at the level of Madyaning Uttama, namely the cremation ceremony of Ngaben Pranawa in accordance with Bhuwanakoûa, namely by not lifting the bodies or skeletons of corpse buried in Setra (graveyard).

To be understood, mostly foreigners who included their deceased families in the ceremony were the sisya (students) who were studying the spiritual practices in the Ratu Bagus Ashram, and Ratu Bagus always conveys the essence of Hindu religion in any event of meditation and shaking to his students. Upon Ratu Bagus explanation, the foreign students had understood and fully assured for taking the Pitrayajña ceremony. Only then the foreigners asked to include their deceased families to be consecrated at the ceremony.

Villagers as the local actors benefitted inwardly and outwardly. They economically obtained additional amounts of money, which was twice the mandatory contribution for each sawa (spirits) that included in the rituals. At that time, the local people put out contribution for each of sawa/spirit as much as Rp. 2,500,000 (two and a half million), while the foreigners contributed as much as $\mathrm{Rp}$. 5.000.000, - (five million rupiah). The foreign participants paid more than the local people, because they were not recorded as official residents in the village, and the foreign participants were considered more capable in terms of economy or finance. The inward benefit was the sense of fun and happness, everyone was actively participated in the ceremony. The foreign participants, in addition to providing the money according to the obligations imposed respectively, they had to participate to follow all activities of mutual cooperation (ngayah). to carry the spirit symbol on the head, to carry the ritual paraphernalia on the shoulder, to carry the Balinese gamelan, and to worship like the Hindus in Bali.

\section{Motivation}

Motivation is the driving force that force individuals to take action (Schiffman and Kanuk, 2004). This means that motivation moves a person to do something (Deci and Ryan, 2000). Motivation is the foundation of all behavior (Fodness, 1994), including traveling and participating in the religious events.

In addition, there is another important theory of motivation, which is known as the theory of "push and pull". Generally, tourist motivation is defined as the force that makes people to travel. Forces or factors are divided into two groups, namely the factor of "push" (driving / internal forces) and the factor of "pull" (towing / external power). According to this theory, the rating is driven by the motivation of the decision-making process into the trip and pulled by the characteristics of the area of interest. Fush motivation of pushing can be explained by the desire to escape, rest and relaxation, prestige health, and fitness, adventure, social interaction, family togetherness, and joy.

Conversely, pull motivation is determined by the attractiveness of the destination, for example, the beach, the national museum, or traditional culture (Phan, 2010). A shift in demand for tourism products on the quality and value (value for money), has increased dramatically in the tourism industry. Travelers want products and services of higher quality tourism, and want a genuine travel experience. As presented by the WTO (World Tourism Organization):

"Future tourists will 'prefer to live their holiday rather than to spend them', and they do so by engaging in cultural, physical, education and spiritual activities"(WTO, 1985) 


\section{Results and Discussion}

The research results showed that the tourists spent much of their time in selfdevelopment rather than just sunbathe on the beach or the pool, they learned the culture, interacted with the indigenous communities, studied spiritual practices, history and the local traditions. Segments of such tourism have been growing rapidly, not only because of various limitations in their home countries, but they also want to be more active and take on an important role, as well as use the opportunity for the development and exploration of the self (Weiler and Hall, 1992; Ryan, 1997). Additionally, in an effort to develop themselves and their personality, a lot of tourists who ultimately chose spiritual tourism (yoga, meditation), although sometimes they do not realize that what they are doing is part of a tourism.

One of the foreign participants in the ceremony of Pitrayajña was Tilda Tucker, from England. She said that the main motive to come to Bali was to follow along and learn the shaking meditation. She most enjoyed the presence and the teachings of Ratu Bagus, the practice of meditation, community life in the Ashram and other exercises program. Tilda said the reason for her participation in the ceremony of Pitrayajña was only through intuition, that karma of her family would be cleared, and drove her family into a higher consciousness. She said that she really enjoyed the life of the ashram community, including the local community; participation in the ceremony of Pitrayajña was a strong relationship between her, the community and their family. For her, she felt connected with the teachings of Ratu Bagus, be individuals who are quieter, have a broader perspective, she understands the correlation between the mind and soul, and conscious of its responsibility to maintain the soul. (Interview with Tilda Tucker, UK, 51: 2011)

http://ojs.unud.ac.id/index.php/eot
Ofir, from Israel, and he has been several times to Bali. He said that his main motivation to come to Bali was to study the energy (Bio Energy) through meditation and increase spirituality. Ofir decided to participate in the ceremony of Pitrayajña in the Pakraman of Muncan, because he wanted to connect again spiritually to his late father, in the ceremony he felt a very strong spirituality. In addition, based on the teachings of Ratu Bagus, he wanted to help his father's atma (soul) in the afterlife, in order to obtain a better place, namely in the Pitraloka. Ofir said that in the Ashram of Ratu Bagus, he shared his experiences in terms of strength and energy, when the powers were not deterred by the thought, he felt himself connected with God, and experienced a variety of healing from the pain, he was then able to penetrate the boundaries within him, it was felt as a freedom.

Not all respondents admitted that they were tourists, as expressed by Sadhya, from the Netherlands. He stated that he was not a tourist, and he came for other purposes. However, he also said that he had come twice to Bali, watched some Balinese traditional dances, he liked the natural scenery such as paddy fields, beaches and mountains, and loved the way of life of the artistic Balinese society. One of the main motives was a spiritual awakening as the result of spiritual practice in the Ashram of Ratu Bagus. For Sadhya, spiritual experience in the Ashram was extraordinary and total, while the reason for participating in the ceremony was he wanted to experience the participation in the ceremony of Pitrayajña personally and deeply, as well as to be connected spiritually with his parents and uncle (Interview with R. J van Sadhya os, March 28, 2012). Perhaps, he did not realize that there are many forms of tourism, one of which is to conduct spiritual tourism in the Ashram of Ratu Bagus, including participating in the ceremony of Pitrayajña. He said that by following meditation training program at Ashram of Ratu 
Bagus, he was able to clean up the various barriers in him, to be healthier human being physically and spiritually. He felt happy, enlightened, energetic, and have compassion for others and themselves. For him, Ratu Bagus Ashram is a beautiful place, aesthetic, loving and luminous, the people were very friendly with an open heart, and people are treated very well.

Marianna Stacey, a musician and a German citizen, but raised in England, was one of the foreign students at the Ashram of Ratu Bagus. She first visited the Ashram in 2003 and thereafter has repeatedly come to Bali. Marianna knew about Ratu Bagus when she attended a conference on healing, and retreat in Germany in 2002. For him, life in Bali was very different from the country of origin. She expected that by participating in this Pitrayajña ceremony, she was able to reconnect with her late husband, and brought back fond memories about her husband. Besides, it was to help her husband's spirit to a better stage. For her, her late husband was very close to, around her, and often helped her in various ways.

The religious ceremonies, social life and the unique Balinese culture are reflected in the behavior of people in the Desa Pakraman of Muncan, especially in the Ratu Bagus Ashram. This is the main attraction for spiritual travelers who come there. All foreign respondents stated that they were interested and motivated to follow the ceremony of Pitrayajña, because they were confident and believe in the truth of the teachings of Yoga of Ratu Bagus.

\section{The Impacts on the Local Community}

Pitrayajña ceremony held collectively in the Desa Pakraman of Muncan, brought many positive benefits for society. The the most widely perceived benefit was the efficiency of resources, both time, energy, thoughts and funding. The second benefit was

http://ojs.unud.ac.id/index.php/eot the growing sense of unity and cooperation in the wider community, and the third was the spiritual benefit, which was expected by this ceremony that all the spiritual goals can be achieved. In the meantime, the participation of foreigners in the Pitrayajña ceremony in the Desa Pakraman of Muncan resulted in various positive impacts for the local communities. Their participation in local activities (ceremony of Pitrayajña), automatically stimulate their social interactions. By social interaction, people can get new insights about things beyond their local knowledge, especially to broaden the understanding of culture. Through cultural exchange, the community of Desa Pakraman of Muncan has been actively participating to promote tourism in Indonesia, among others, by introducing and utilizing the natural beauty and the local culture, as well as increasing national and international brotherhood.

Social interaction between the local people and the foreigners is able to increase the sense of togetherness and brotherhood among them. Similarly, a sense of solidarity to help each other and to cooperate in organizing and holding the ceremony. The local people were proud of that foreigners who sincerely wanted to get together to actively took part in the ceremony. According to the people, the foreign spiritual and cultural travelers were happy and enthusiastic as well as able to learn well.

The perceived positive benefit for the community was the ease in many ways, in addition to the financial benefits. During the ceremony, it was used a cross-subsidy system. Foreign participants were required to pay contributions twice as much as the local people. In terms of economy, the participation of foreigners in the ceremony indirectly helped the economy; it was profitable for the local small businesses such as fruit sellers, young coconut leaves for making offering baskets, coconut, ritual paraphernalia and others. Thus, the participation of foreigners in the ceremony

e-ISSN: 2407-392X. p-ISSN: 2541-0857 
of Pitrayajña had positive impacts on the people of Desa Pakraman of Muncan in terms of morality, insight, education and the economy, which ultimately could improve the welfare of the rural community.

\section{The Impact on the Participants / Foreigners}

For foreigners who participated in the ceremony of Pitrayajña in the Desa Pakraman of Muncan, they were more motivated to explore the teachings of Hinduism, as they were very confident on the implementation of the Pitrayajña ceremony.

Tilda was very happy and grateful to have been allowed to participate in the ceremony of Pitrayajña and feel blessed to be in the Ashram. To her, the Pitrayajña ceremony was very beautiful, elaborate, a wonderful experience that was very touching, and like a gift. After the ceremony, she wanted to know more about the details of the ceremony truth and the teachings of Hinduism in it.

Ofir, deeply felt his spirituality when he took part in the Pitrayajña ceremony, where many people were involved and it was a great ceremony. He said that he understood the intent and philosophy of the ceremony, though not too detailed.

As for Sadhya, Pitrayajña ceremony that he attended was very beautiful, he felt it as a gift from Ratu Bagus on him, the ceremony was enabled many people to give a dignified farewell to the deceased beloved ones. However, for him, the ceremony took a very long time, and a little complicated. Sometimes he felt that there was too much focus on the 'shape' than the inner meaning, about the essence or philosophy of cremation for the loved ones. He wanted a little ceremony of 'phisical form', although it was beautiful.

http://ojs.unud.ac.id/index.php/eot

\section{Spiritual Meanings}

Post-Religious theory is beyond the concept of the meaning of spirituality and the governance rules of religion, because spirituality is connecting people directly with the absolute essence that wants to accomplish (the religious call Him by many names, such as God, Allah, and others). Related to this, the foreigners who participated in the Pitrayajña cremation ceremony for their deceased family (Ngaben, mamukur and Ngalinggihang Dewa Hyang) are students of Ratu Bagus. They believed that their parents will be very happy when they took part of the Pitrayajña ceremony at Ratu Bagus Ashram.

Hindu doctrine reflects the tolerance and just owned by God. So that Hinduism considers all religions are having the same goals, only the viewpoints and the ways of implementation are different, because Hinduism respects the truth that comes from all directions. Although the foreigners who participated in the ceremony of Pitrayajña was not Hindus formally, but they believed in the teachings and truths of the Hindu religion. They tend to choose a more pure spirituality that is free, compared to embrace or to have religious conversion.

\section{The Social and Cultural Meanings}

In the Balinese culture, there is suspicion that the people who conducted the Balinese ceremonies (Hindu), should be a Hindu. But in the Pitrayajña ceremony in the Desa Pakraman of Muncan, many foreigners were involved and participated. Formally, they were not Hindus. Deconstruction Theory appropriately discusses this phenomenon. In accordance with the understanding of Deconstruction, the participation of foreign people have given paradoxical and contradictory meaning to the beliefs that are prevalent in society. According to this theory, the ceremony of Pitrayajña has been deconstructed in such a way that it is 
understood as a universal ceremony, as long as they believed in the truth and obeyed all rules and regulations in the ceremony. It was proved that tourism (in this case: the spiritual tourism) has been able to change the order of history, behavior and traditions of the local communities to be in accordance with their interests.

Participation of foreigners who were not formally Hindus in the Pitrayajña ceremony has demonstrated the failure of efforts to bring the absolute truth, that mentions only the Balinese (Hindus) who were allowed to undertake this ceremony. Participation of foreigners in the Pitrayajña ceremony has brought down the hierarchy to something that became a fixed rule in society, and it found another meaning behind the philosophy, i.e. the meaning was reconstructed for the own sake of society.

\section{Economic Meanings}

The implementation of Pitrayajña ceremony in the Desa Pakraman of Muncan was held collectively. Thus, the financial burden on society can be reduced, thanks to the cross-subsidy system implemented since the beginning. In addition, the ceremony of Pitrayajña was able to help the economy of the community and the surrounding areas within the Desa Pakraman of Muncan. Participation of foreign people have been able to inspire the spiritual tourism development in the village. This will provide economic benefits, especially for the local people of Desa Pakraman of Muncan, and the Balinese people in general.

http://ojs.unud.ac.id/index.php/eot

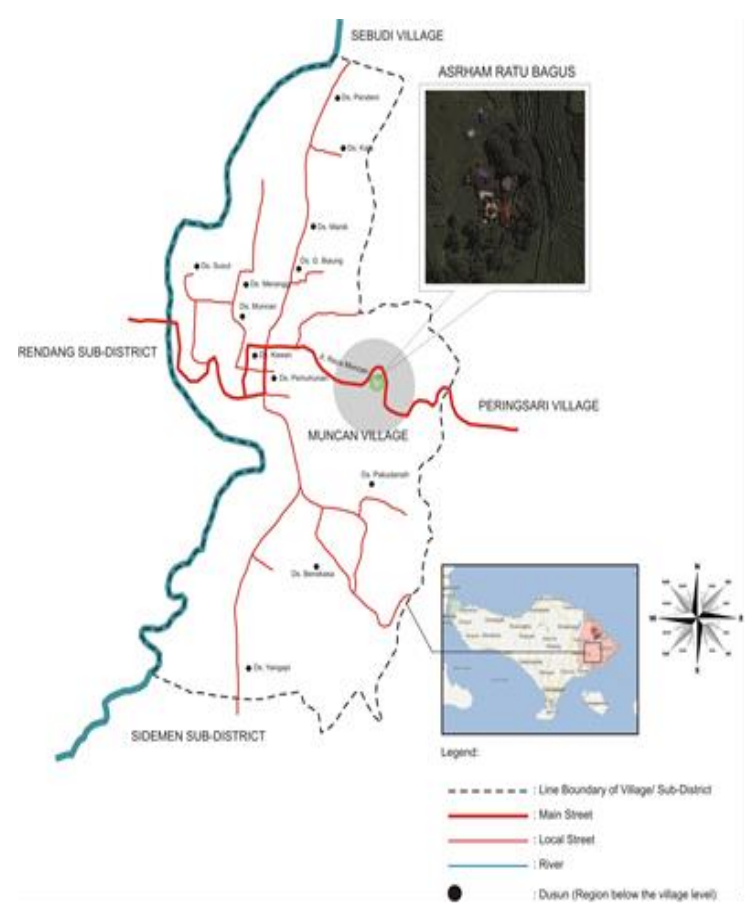

Figure 1. Location Map of Desa Pakraman of Muncan, Karangasem, Bali

\section{Conclusion}

Firstly, the tourists visiting Bali not only undertaking conventional tourism. A small portion of them choose alternative activities such as spiritual tourism. The foreigners are always trying to get into the "back region" of the places they visit, because the area is always associated with intimacy and authenticity of an experience. In this case, the "front region" and "back region", there is a 'space' that is designed to accommodate and support the beliefs of the authenticity of their experience. By participating in the Pitrayajña ceremony, they actually have successfully entered the "back region" and get an authentic experience.

Secondly, there were different types of motivation associated with their participation in the Pitrayajña ceremony. The main motivation were the desire to "reconnect" with their deceased loved ones and to help their spirits attain a better place, as well as efforts to "clear" their family karmas. Moreover, in their spiritual journey, they also learned and 
practiced yoga and meditation of Bio Energy in the Ratu Bagus Ashram. Through this ceremony, they were trying to increase their spirituality phase. For them, it also could bring physical and emotional healings.

Thirdly, most people assume that foreign participation in the ceremony of Pitrayajña can bring a positive impact, particularly in terms of economic and sociocultural interaction between them and the locals. Participation of foreigners bring positive motivation and a sense of pride in the community, as well as being the spiritual inspiration for the development of tourism in the future of Bali.

The findings indicated that spirituality cannot be bound by religious or institutional rules; this case proves the universality and flexibility of Hinduism. The generalization that cremation is only for Hindus and the Balinese has been reversed by using the theory of deconstruction. However, it is still perceived to be lack of clear-cut regulations from the authorities, and there are no clear standard rules on the participation of foreigners in various ceremonies in Bali. Hopefully, by the clear regulations can prevent conflicts that may occur in the future.

\section{References}

Ardika, I. W. (2004) 'Pariwisata Bali: Membangun Pariwisata Budaya dan Mengendalikan Budaya Pariwisata', Dalam Bali Menuju Jagadhita: Aneka Perspektif. Denpasar: Pustaka Bali Post.

Basham, A. L. (1984) 'The Wonder That Was India. 1954', London, Sidgwick and Jackson.

Dakshinaranjan, S. (1990) 'Origin and Development of The Rituals of Ancestor Worship in India'. Calcuta, India: Bookland Private Limited.
Deci, E. L. and Ryan, R. M. (2000) "The" what" and" why" of goal pursuits: Human needs and the selfdetermination of behavior', Psychological inquiry. Taylor \& Francis, 11(4), pp. 227-268.

Eade, J. (1992) 'Pilgrimage and tourism at Lourdes, France', Annals of Tourism Research. Elsevier, 19(1), pp. 18-32.

Eiseman, F. B. (2011) Bali: Sekala \& Niskala: Sekala \& Niskala. Tuttle Publishing.

Fodness, D. (1994) 'Measuring tourist motivation', Annals of tourism research. Elsevier, 21(3), pp. 555581.

Forshee, J. (2006) Culture and customs of Indonesia. Greenwood Publishing Group.

Klostermaier, K. K. (1990) A Survey of Hinduism. New Delhi, India: Munshiram Manoharlal.

Nurgiyantoro, B. (1995) Teori pengkajian fiksi. Gadjah Mada University Press.

Phan, T. K. L. (2010) 'Tourist motivation and activities: a case study of Nha Trang, Vietnam'. Universitetet i Tromsø.

Picard, M. (2006) Bali: PariwisataBudaya, BudayaPariwisata. Jakarta: KepustakaanPopulerGramedia.

Pradopo, R. D. (1990) Pengkajian Puisi. Yogyakarta: UGM Press.

Relin, D. E. (2011) 'Pemertahanan tradisi Ruwatan dalam era modernisasi dalam masyarakat Jawa di desa Kumendung, Muncar, Banyuwangi, Jawa Timur'.

Ryan, C. (1997) 'The Chase of a Dream, the End of a Play', The tourist experience: A new introduction. Cassell London, pp. 1-24.

Sastropoetro, R. A. S. (1988) 'Partisipasi Komunikasi, Persuasi dan Dispilin dalam Pengembangan Pembangunan', Penerbit Alumni. Bandung. 
Schiffman, L. G. and Kanuk, L. L. (2004) 'Consumer behaviour 8 th ed', NY: Prentice-Hall Inc.

Shackley, M. (2006) 'Keynote Address: Tourism-The Spiritual Dimension', in Tourism: The Spiritual Dimension Conference. University of Lincoln, UK.(Unpublished). In Sharpley, pp. 237-253.

Siahaan, H. M. (1986) Pengantar ke Arah Sejarah dan Teori Sosiologi. Available at: http://ratnandoet.wordpress.com/2010/ 12/25/teori-tentang-agama-emiledurkheim/ (Accessed: 2 June 2012).

Stausberg, M. (2011) Religion and tourism: crossroads, destinations, and encounters. Routledge.

Suardana, I. K. (2010) 'Persepsi Wisatawan Terhadap Desa Ubud: Sebuah Pendekatan Teologi Pariwisata (Perceptions of Tourists About the Ubud village: A Theological Tourism Approach)'. Thesis. Institut Hindu Dharma Negeri Denpasar.

Suastini, N. N. (2007) 'Upacara Ngaben Matempung Di Desa Gadungan Kecamatan Selemadeg Timur Kabupaten Tabanan: Analisis Bentuk, Fungsi dan Makna,(Ngaben Matempung Ceremony in Gadungan Village, East Selemadeg, Tabanan: Analysis of Forms, Fucntions and Meanings)'. Thesis Magister Brahma Widya, Institut Hindu Dharma Negeri Denpasar.

Suciati (2006) 'Partisipasi Masyarakat dalam Penyusunan Rencana Umum Tata Ruang Kota Pati'. program Pascasarjana Universitas Diponegoro.

Titib, I. M. (2006) Persepsi umat Hindu Bali terhadap svarga, naraka, dan mokșa dalam Svargarohanaparva: perspektif kajian budaya. Penerbit Pāramita.

Weiler, B. and Hall, C. M. (1992) Special interest tourism. Belhaven Press.
WTO (1985) 'The Role of Recreation Management in the Development of Active Holidays and Special Interest Tourism and Consequent Enrichment of the Holiday Experience'. Madrid: WTO. 